ORIGINAL ARTICLE

\title{
A comparative analysis of abandoned street children and formerly abandoned street children in La Paz, Bolivia
}

\author{
C-C Huang, P Barreda, V Mendoza, L Guzman, P Gilbert
}

Arch Dis Child 2004;89:821-826. doi: 10.1136/adc.2003.042911

See end of article for authors' affiliations

Correspondence to:

Dr C Huang, Department

of Pediatrics, Dowling 3

South, One Boston

Medical Center Place,

Boston, MA 02118-2393,

USA; chuang30@hotmail.

com

Accepted 4 March 2004
Aims and Methods: A comparative study of abandoned street children and formerly abandoned street children was conducted in La Paz, Bolivia, representing the first such comparative assessment. Between August and December 1997, all abandoned street children in La Paz, Bolivia, who were willing to participate $(n=124)$ were interviewed repeatedly at night using standardised questionnaires to collect information on family history, demographics, socioeconomics, drug use, and physical/sexual abuse. The same questionnaires were administered to all former abandoned street children who chose to enter a local orphanage $(n=35)$.

Results: The persistent street children differed greatly from those who entered the orphanage, most markedly in their higher risk of police abuse (95\% versus 38\%), absence from school ( $84 \%$ versus $19 \%$ ), engagement in robbery (26\% versus $4 \%)$, paint thinner use $(88 \%$ versus $41 \%)$, alcohol use $(58 \%$ versus $12 \%)$, and a serious medical problem (53\% versus $20 \%)$. The risks for street children increased rapidly with age.

Conclusions: A cascade of adverse outcomes afflicts the vast majority of abandoned street children in La $\mathrm{Paz}$, which cumulate with age and diminish the likelihood of successful rehabilitation through lasting placement in an orphanage or residential home. Informed by these findings, the investigators operate a home for abandoned street children in La Paz.
A ccording to estimates from the United Nations, millions of street children live in the various cities around the world, with a large proportion residing in Latin America and Africa. ${ }^{1}$ Bolivia is not immune to this human tragedy, with 72000 street children in 1994 according to UNICEF. ${ }^{2-4}$ The general public has labelled children without a home with derogatory terms such as "urchins, little bugs, little criminals, fruit birds, dirty faces, vermin, mosquitoes, or little farts." ${ }^{56}$ Some view the children as so undesirable in society that government institutions, police, and vigilante groups have killed them. The most famous case occurred in 1997 in Brazil, where the police death squad shot at approximately 50 street children, killing five. According to a poll taken a few days later, the majority of the public approved of the actions. ${ }^{78}$ Such inhumane violence represents a lack of understanding of the life of street children and a lack of will to constructively face such a momentous societal issue.

UNICEF categorises street children into three groupings. ${ }^{9}$ "Children at risk" are defined as poor children with particular risk factors, such as poverty and lack of schooling, ${ }^{10}$ that may lead to their partial expulsion from the home and spending a portion of their life on the streets. "Children on the street" work on the streets during the day and return home at night. Their jobs often consist of menial labour, such as shoe shining, selling candy and other goods, washing and guarding cars, or carrying goods. "Children of the streets" have very limited family contact and live and sleep on the streets with little, if any, adult supervision. ${ }^{5}$ Another category of street children is "abandoned street children", who have no contact with their parents whatsoever (very young street children whose parents are abandoned street children are included in the definition of abandoned street children). ${ }^{10}$

Because of the difficulties in gaining the confidence of the children and entering into their world and underground culture, most investigations have focused on children on the streets instead of children of the streets..$^{8^{11-15}}$ Over the last six years, our team has worked at unconventional hours to befriend and understand the Bolivian abandoned street child population. In addition, many studies have only taken "snapshots" of the lives of the children, with researchers and street workers gathering questionnaire data during the day over brief spans of time. In order to improve the understanding of these children, the investigators must break the adult-child barrier and develop friendships, which inevitably takes time. This study focused on a relatively confined region of La Paz, Bolivia in order to quantitatively define "abandoned street children". ${ }^{10}$ To aid the description, we determined statistically significant differences between abandoned street children currently of the streets and former abandoned street children who lived at a nearby orphanage. The purposes of this study were to describe the abandoned street children, focusing on gender differences, and to compare those children to children who chose to enter an orphanage.

\section{METHODS}

\section{Collection of data from street children}

The study was conducted in downtown La Paz, Bolivia, from 1 August 1997 to 31 December 1997. The investigation focused on 124 abandoned children of the street. The catchment area for the street children consisted of four main sections of downtown $\mathrm{La} \mathrm{Paz}$ within a $7 \mathrm{~km}^{2}$ region, in which children resided at night on a semi-permanent basis.

The investigators performed the majority of the fieldwork interviews between $10 \mathrm{pm}$ and 3 am four nights every week. Standardised questionnaires were used to obtain information on sex, age, general location of street residence, time period on the street, past socioeconomic family and educational history, offspring and pregnancy status, reason for living on the street, method of income, health problems, drug and alcohol use, physical and sexual abuse, and problems with the police. Interviews were conducted at night because the street children could be consistently located at night in a 
general downtown location, and were more amenable to interviews than during the day. Street youth were difficult to find by day because they tended to work in several regions of the city. To ensure uniformity of data collection, the nightly interviews were always conducted in the $10 \mathrm{pm}$ to 3 am time window.

Field observations were conducted in the children's natural settings. This served three purposes. First, the investigators sought to obtain the trust and confidence of the children. To this end, the researchers devoted at least 40 hours every week to spending time with the street youth and providing medical care. Second, this extensive observation permitted accurate classification of the children as abandoned street children. Third, observing the children in their natural environment was essential for understanding many characteristics such as the daily work schedule, method of obtaining drugs, time spent in the penitentiary, and various forms of play. Repeated interviews were administered in order to reconfirm the data and to minimise missing data.

\section{Collection of data from Alalay and Marcelina orphanage residents}

The Alalay and Marcelina orphanages are entry-level street child facilities, for boys and girls, respectively. As a comparison group, the same questionnaires as used for street children were administered to children living in these local orphanages who prior to entering the orphanage were abandoned street children $(\mathrm{n}=35)$. The orphanage residents were interviewed numerous times about their former lives on the streets, so that the comparisons assess differences among street children who entered Alalay/Marcelina versus street children who had not entered any orphanage. The orphanages admit all willing children with no exclusion criteria. The majority of entering residents had not previously lived on the street, which consisted of children brought to the homes by their parents and run-away children. The remaining orphanage residents were abandoned street children who entered the orphanage voluntarily on their own accord, without referral from an institution or the authors. The authors formed relationships with all of the orphanage residents through delivery of regular medical checkups, and selected all formerly abandoned street children for participation in the study.

All 35 orphanage residents identified as formerly abandoned street children participated in the study, and greater than $90 \%$ of the abandoned street children participated in the study. Therefore the studied children were not highly selected for their willingness to participate, and they are fairly representative of the whole populations of abandoned and formerly abandoned street children in the selected areas of downtown La Paz.

\section{Statistical methods}

Fisher's exact and $\chi^{2}$ tests were used to compare categorical variables between groups, and $t$ tests were used to compare continuous variables between groups. Partial F-tests in multiple linear regression models were used to compare continuous outcomes between groups controlling for age. Logistic regression models were used to estimate odds ratios for being on the street versus being in the orphanage, unadjusted or adjusted for age. ${ }^{16}$ Likelihood ratio deviance statistics were used for testing whether unadjusted or adjusted odds ratios differed significantly from one. Age was controlled for because it is a proxy for the time at risk for several of the outcome variables. All analyses were conducted using Stata version 7.0 software (Stata Corporation, College Station, Texas). All hypothesis tests were two tailed, with significance judged by a $\mathrm{p}$ value less than 0.05 .
This study was a medical student project at Harvard Medical School (HMS) proposed in 1997 by the first author. As attested by a letter from HMS, ethical approval of the project was granted by the master of HMS's Academic Society and by the Dean of Harvard Medical School and the HMS's Faculty Council.

\section{RESULTS}

\section{Sociodemographic characteristics of abandoned} street boys and abandoned street girls

As summarised in table 1, we studied 124 abandoned street children ranging in age from 3 to 18 years, of whom $39(31 \%)$ were female. The children had been on the street for an average of 4.1 years. Most of the children came from homes of abject poverty or lower socioeconomic class. The children stated that they became street youth due to physical abuse $(40 \%)$, parental death (18\%), abandonment (16\%), mental abuse $(13 \%)$, and lack of financial resources to support them (7\%). Once the abandoned street children permanently left home and disassociated themselves with any adults, they earned their living and survived by working in the informal sector-begging (32\%), robbery $(26 \%)$, singing on the buses $(14 \%)$, shining shoes $(10 \%)$, and selling various goods on the streets (10\%). Moreover, we discovered that the children had not had any formal schooling on average for three to four years. This study indicates that street girls were significantly older than street boys (mean 16.3 years versus 13.5 years, $\mathrm{p}<0.001$ ), had more infants for which they were directly responsible, and earned an income through selling items compared to robbery, shining shoes, or singing on the bus.

\section{Health characteristics of abandoned street boys and abandoned street girls}

Over half of the children (53\%) reported health problems. The most prevalent complaints were musculoskeletal pain $(n=14)$, wounds or contusions inflicted by violence or selfabuse $(n=10)$, dental caries $(n=10)$, generalised abdominal pain $(n=7)$, a minor skin infection $(n=4)$, upper respiratory illness $(n=7)$, and sexually transmitted disease $(n=3)$. In addition, $88(85 \%)$ of the children reported the experience of some form of physical abuse committed by street children $(36 \%)$, relatives $(31 \%)$, police force $(21 \%)$, or self-mutilation $(12 \%)$. Of the 92 street children reporting their interactions with the police, nearly all (95\%) reported problems with the police, such as derogatory comments, rape, financial extortion, and physical beating. Moreover, 15 children (20\%) admitted to being a victim of sexual abuse, and identified the perpetrator as a close relative $(n=6)$, another street child $(n=4)$, a policeman $(n=2)$, or a customer in prostitution $(\mathrm{n}=3)$. Comparatively, street girls were more commonly victimised by sexual abuse (38\% versus 9\%, $p=0.0019$ unadjusted for age) compared to boys; this difference is partly due to the older age of girls-it became non-significant after controlling for age $(p=0.15)$. The perpetrator of physical abuse was more frequently self for girls (19\% versus $9 \%$ ) and the police for boys (15\% versus $24 \%$ ). The street children's lives were nearly universally consumed with the use of the combination of inexpensive drugs, specifically paint thinner at $88 \%$, alcohol at $58 \%$, and glue adhesive at $40 \%$.

\section{Sociodemographic and health characteristics of abandoned street children and formerly abandoned street children in the Alalay and Marcelina orphanages}

The street children had very different characteristics than the children residing in the orphanage, with 13 variables differing significantly (tables 1 and 2, columns 5-7). Results were comparable whether or not age was controlled for, except that the differences for duration of time on the street 


\begin{tabular}{|c|c|c|c|c|c|c|}
\hline Characteristic & $\begin{array}{l}\text { Street boys } \\
(\mathrm{n}=85)\end{array}$ & $\begin{array}{l}\text { Street girls } \\
(n=39)\end{array}$ & $\begin{array}{l}\text { Comparison of } \\
\text { street boys and } \\
\text { street girls* }\end{array}$ & $\begin{array}{l}\text { Street children } \\
(n=124)\end{array}$ & $\begin{array}{l}\text { Orphanage } \\
(n=35)\end{array}$ & $\begin{array}{l}\text { Comparison of street } \\
\text { and orphanage } \\
\text { children* }\end{array}$ \\
\hline Age $(y)$ & $n=85$ & $n=39$ & $\mathrm{p}<0.001 / \mathrm{N} / \mathrm{A}$ & $n=124$ & $\mathrm{n}=35$ & $p<0.001 / N / A$ \\
\hline$\leqslant 10$ & $14(16 \%)$ & $1(3 \%)$ & & 15 (12\%) & $15(43 \%)$ & \\
\hline $11-15$ & $48(56 \%)$ & $9(23 \%)$ & & $57(46 \%)$ & 19 (54\%) & \\
\hline $16-20$ & $23(27 \%)$ & $29(74 \%)$ & & $52(42 \%)$ & $1(3 \%)$ & \\
\hline Average (SD) & $13.5(3.2)$ & $16.3(2.6)$ & & $14.4(2.9)$ & $11.4(2.5)$ & \\
\hline Years spent on the street & $n=79$ & $n=36$ & $p=0.78 / 0.17$ & $\mathrm{n}=115$ & $n=27$ & $p<0.001 / 0.022$ \\
\hline $0-1$ & $14(18 \%)$ & $9(25 \%)$ & & $23(20 \%)$ & $17(63 \%)$ & \\
\hline $2-5$ & $49(62 \%)$ & $16(44 \%)$ & & $65(56 \%)$ & $7(26 \%)$ & \\
\hline $6-15$ & $16(20 \%)$ & $11(31 \%)$ & & $27(24 \%)$ & $3(11 \%)$ & \\
\hline Average (SD) & $4.1(3.2)$ & $4.0(3.2)$ & & $4.1(3.2)$ & $1.9(2.4)$ & \\
\hline Years in orphanage & N/A & $N / A$ & N/A & N/A & $n=23$ & N/A \\
\hline $0-1$ & & & & & $8(35 \%)$ & \\
\hline $2-5$ & & & & & $10(44 \%)$ & \\
\hline $6-15$ & & & & & $5(22 \%)$ & \\
\hline Average (SD) & & & & & $0.9(1.3)$ & \\
\hline Mother's occupation & $n=37$ & $n=21$ & $p=0.17 / 0.40$ & $\mathrm{n}=58$ & $n=23$ & $p=0.026 / 0.013$ \\
\hline No employment & $0(0 \%)$ & $2(10 \%)$ & & $2(3 \%)$ & $2(9 \%)$ & \\
\hline Low salary & $27(73 \%)$ & $15(71 \%)$ & & $42(72 \%)$ & $20(87 \%)$ & \\
\hline Medium salary & $1(3 \%)$ & $1(5 \%)$ & & $2(3 \%)$ & $1(4 \%)$ & \\
\hline Dead & $9(24 \%)$ & $3(14 \%)$ & & $12(21 \%)$ & $0(0 \%)$ & \\
\hline Father's occupation & $n=29$ & $n=21$ & $p=0.068 / 0.27$ & $n=50$ & $n=19$ & $p=0.34 / 0.53$ \\
\hline No employment & $2(7 \%)$ & $2(10 \%)$ & & $4(8 \%)$ & $1(5 \%)$ & \\
\hline Low salary & $17(59 \%)$ & $10(48 \%)$ & & $27(54 \%)$ & $14(74 \%)$ & \\
\hline Medium salary & $0(0 \%)$ & $4(19 \%)$ & & $4(8 \%)$ & $2(10 \%)$ & \\
\hline High Salary & $1(3 \%)$ & $1(5 \%)$ & & $2(4 \%)$ & $0(0 \%)$ & \\
\hline Dead & $9(31 \%)$ & $4(19 \%)$ & & $13(26 \%)$ & $2(10 \%)$ & \\
\hline Years since in school & $n=47$ & $n=15$ & $p=0.97 / 0.14$ & $n=62$ & $n=26$ & $p<0.001 / 0.001$ \\
\hline In school & $7(15 \%)$ & $3(20 \%)$ & & $10(16 \%)$ & $21(81 \%)$ & \\
\hline 1 month-1 year & $9(19 \%)$ & $2(13 \%)$ & & $11(18 \%)$ & $3(12 \%)$ & \\
\hline $2-5$ years & $18(38 \%)$ & $7(47 \%)$ & & $25(40 \%)$ & $0(0 \%)$ & \\
\hline $6-15$ years & $13(28 \%)$ & $3(20 \%)$ & & $16(26 \%)$ & $2(8 \%)$ & \\
\hline Avg. years since in school (SD) & $3.8(3.2)$ & $3.1(3.2)$ & & $3.6(3.2)$ & $0.6(1.9)$ & \\
\hline Have children? & $n=47$ & $n=23$ & $p<0.001 / 0.070$ & $n=70$ & $n=1$ & N/A \\
\hline Yes & $4(9 \%)$ & $10(44 \%)$ & & $14(20 \%)$ & $0(0 \%)$ & \\
\hline Reason for being on street & $n=78$ & $n=37$ & $p=0.97 / 0.82$ & $\mathrm{n}=115$ & $n=34$ & $p=0.10 / 0.04$ \\
\hline Physical abuse & $31(40 \%)$ & $15(40 \%)$ & & $46(40 \%)$ & $19(56 \%)$ & \\
\hline Parental death & $16(20 \%)$ & $5(14 \%)$ & & $21(18 \%)$ & $7(21 \%)$ & \\
\hline Abandonment & $13(17 \%)$ & $6(6 \%)$ & & $19(16 \%)$ & $2(6 \%)$ & \\
\hline Mental abuse & $10(13 \%)$ & $5(14 \%)$ & & $15(13 \%)$ & $0(0 \%)$ & \\
\hline Lack of financial resources & $5(6 \%)$ & $3(8 \%)$ & & $8(7 \%)$ & $3(9 \%)$ & \\
\hline Other & $3(4 \%)$ & $3(8 \%)$ & & $6(5 \%)$ & $3(9 \%)$ & \\
\hline Method of income & $\mathrm{n}=75$ & $n=31$ & $p<0.001 /<0.001$ & $n=106$ & $n=26$ & $p=0.0015 /<0.001$ \\
\hline Begging & $23(31 \%)$ & $11(36 \%)$ & & $34(32 \%)$ & $3(12 \%)$ & \\
\hline Robbery & $24(32 \%)$ & $4(13 \%)$ & & $28(26 \%)$ & $1(4 \%)$ & \\
\hline Singing on the bus & $14(19 \%)$ & $1(3 \%)$ & & $15(14 \%)$ & $9(35 \%)$ & \\
\hline Shining shoes & $9(12 \%)$ & $2(6 \%)$ & & 11 (10\%) & $5(19 \%)$ & \\
\hline Selling items & $3(4 \%)$ & $8(26 \%)$ & & $11(10 \%)$ & $1(4 \%)$ & \\
\hline None & $0(0 \%)$ & $0(0 \%)$ & & $0(0 \%)$ & $1(4 \%)$ & \\
\hline Other & $2(3 \%)$ & $5(16 \%)$ & & $7(6 \%)$ & $6(23 \%)$ & \\
\hline
\end{tabular}

and for duration of paint thinner and alcohol use were smaller under age-adjustment (these attenuated effects occurred because street children were older on average than orphanage residents). Throughout the remainder of this results section age adjusted $\mathrm{p}$ values are presented. Street children were older (mean 14.4 years versus 11.4 years, $\mathrm{p}<0.001$ ), had spent more time on the street (for example, $80 \%$ versus $37 \%$ greater than one year, $p=0.022$ ), were more likely to have a dead mother $(p=0.013)$, were out of school much longer (for example, average 3.6 versus 0.6 years since last schooling, $\mathrm{p}=0.001$ ), and were more likely to be on the street because of parental abandonment or mental abuse $(p=0.04)$. Moreover, abandoned street children had a much higher frequency of illicit drug use, were more likely to be abused physically ( $85 \%$ versus $59 \%, p=0.045$ ), and had a far greater frequency of problems with the police (95\% versus $38 \%, \mathrm{p}<0.001)$ than the former abandoned street child population.

In logistic regression models controlling for age, problems with police (odds ratio (OR) 8.0, 95\% confidence interval (CI)
2.4 to $26.6, \mathrm{p}<0.001$ ), earning income by begging rather than shoe shining $(\mathrm{OR}=8.4,95 \% \mathrm{CI} 1.4$ to $48.3, \mathrm{p}=0.010)$, and an older age $(\mathrm{OR}=1.19 /$ year, $95 \%$ CI 0.96 to 1.47 , $\mathrm{p}=0.058$ ) predicted paint thinner use. An older age also predicted alcohol use $(\mathrm{OR}=1.15 /$ year, $95 \%$ CI 1.1 to 1.6 , $\mathrm{p}<0.001)$, as did longer duration on the street $(\mathrm{OR}=1.2$ / year, $95 \%$ CI 1.0 to $1.3, \mathrm{p}=0.008)$, being on the street due to physical abuse compared to emotional abuse (OR $=17.9,95 \%$ CI 2.0 to $162.9, \mathrm{p}<0.001$ ), and earning income by begging rather than by singing on the bus $(\mathrm{OR}=6.2,95 \% \mathrm{CI} 1.1$ to $36.6, p=0.031)$. The only significant predictor of glue adhesive use was sexual abuse (OR $=3.4,95 \%$ CI 1.1 to 10.7 , $\mathrm{p}<0.001)$.

\section{Factors significantly associated with being on the street versus in the Alalay or Marcelina orphanages in logistic regression models}

Finally, using a logistic regression model controlling for age, the relation between each variable and the odds of being on the street as compared to being in the Alalay or Marcelina 
Table 2 Health characteristics of abandoned street boys and girls, and formerly abandoned street children in the Alalay and Marcelina orphanages

\begin{tabular}{|c|c|c|c|c|c|c|}
\hline Characteristic & $\begin{array}{l}\text { Street boys } \\
(n=85)\end{array}$ & $\begin{array}{l}\text { Street girls } \\
(\mathrm{n}=39)\end{array}$ & $\begin{array}{l}\text { Comparison of } \\
\text { street boys and } \\
\text { street girls* }\end{array}$ & $\begin{array}{l}\text { Street children } \\
(n=124)\end{array}$ & $\begin{array}{l}\text { Orphanage } \\
(\mathrm{n}=35)\end{array}$ & $\begin{array}{l}\text { Comparison of street and } \\
\text { orphanage children* }\end{array}$ \\
\hline $\begin{array}{l}\text { Report of a health problem } \\
\text { Yes }\end{array}$ & $\begin{array}{l}n=85 \\
37(44 \%)\end{array}$ & $\begin{array}{l}n=39 \\
29(74 \%)\end{array}$ & $p=0.003 / 0.007$ & $\begin{array}{l}n=124 \\
66(53 \%)\end{array}$ & $\begin{array}{l}n=35 \\
7(20 \%)\end{array}$ & $\mathrm{p}<0.001 /<0.001$ \\
\hline $\begin{array}{l}\text { Use of paint thinner } \\
\text { Yes }\end{array}$ & $\begin{array}{l}n=75 \\
65(87 \%)\end{array}$ & $\begin{array}{l}\mathrm{n}=35 \\
32(91 \%)\end{array}$ & $p=0.24 / 0.35$ & $\begin{array}{l}\mathrm{n}=110 \\
97(88 \%)\end{array}$ & $\begin{array}{l}n=27 \\
11(41 \%)\end{array}$ & $\mathrm{p}<0.001 /<0.001$ \\
\hline $\begin{array}{l}\text { Duration of paint thinner use } \\
<1 \mathrm{mth} \\
1 \mathrm{mth}-1 \text { y } \\
2-5 y \\
6-15 y \\
\text { Average duration of use, y (SD) }\end{array}$ & $\begin{array}{l}n=53 \\
4(8 \%) \\
11(21 \%) \\
30(57 \%) \\
8(15 \%) \\
3.3(2.8)\end{array}$ & $\begin{array}{l}n=28 \\
3(11 \%) \\
4(14 \%) \\
14(50 \%) \\
7(25 \%) \\
3.7(3.0)\end{array}$ & $p=0.57 / 0.21$ & $\begin{array}{l}n=81 \\
7(9 \%) \\
15(18 \%) \\
44(54 \%) \\
15(18 \%) \\
3.5(2.9)\end{array}$ & $\begin{array}{l}n=10 \\
4(40 \%) \\
5(50 \%) \\
1(10 \%) \\
0(0 \%) \\
0.5(0.9)\end{array}$ & $p=0.002 / 0.020$ \\
\hline $\begin{array}{l}\text { Use of glue adhesive } \\
\text { Yes }\end{array}$ & $\begin{array}{l}n=69 \\
25(36 \%)\end{array}$ & $\begin{array}{l}n=31 \\
15(48 \%)\end{array}$ & $p=0.27 / 0.42$ & $\begin{array}{l}n=100 \\
40(40 \%)\end{array}$ & $\begin{array}{l}n=27 \\
3(11 \%)\end{array}$ & $p=0.0027 / 0.012$ \\
\hline $\begin{array}{l}\text { Duration of glue adhesive use } \\
<1 \mathrm{mth} \\
1 \text { month-1 y } \\
2-5 y \\
6-15 y \\
\text { Average duration of use, y (SD) }\end{array}$ & $\begin{array}{l}n=15 \\
0(0 \%) \\
5(33 \%) \\
9(60 \%) \\
1(7 \%) \\
2.7(2.2)\end{array}$ & $\begin{array}{l}n=9 \\
1(11 \%) \\
0(0 \%) \\
4(44 \%) \\
4(44 \%) \\
4.4(3.4)\end{array}$ & $p=0.14 / 0.40$ & $\begin{array}{l}n=24 \\
1(4 \%) \\
5(21 \%) \\
13(54 \%) \\
5(21 \%) \\
3.4(2.6)\end{array}$ & $\mathrm{n}=0$ & N/A \\
\hline $\begin{array}{l}\text { Use of alcohol } \\
\text { Yes }\end{array}$ & $\begin{array}{l}n=73 \\
41(56 \%)\end{array}$ & $\begin{array}{l}n=33 \\
20(61 \%)\end{array}$ & $p=0.24 / 0.21$ & $\begin{array}{l}n=106 \\
61(58 \%)\end{array}$ & $\begin{array}{l}n=26 \\
3(12 \%)\end{array}$ & $p<0.001 / 0.0025$ \\
\hline $\begin{array}{l}\text { Duration of alcohol use } \\
<1 \mathrm{mth} \\
1 \mathrm{mth}-1 \text { y } \\
2-5 y \\
6-15 y \\
\text { Average duration of use, y (SD) }\end{array}$ & $\begin{array}{l}n=19 \\
1(5 \%) \\
5(26 \%) \\
10(53 \%) \\
3(16 \%) \\
3.2(3.0)\end{array}$ & $\begin{array}{l}n=12 \\
1(8 \%) \\
2(17 \%) \\
6(50 \%) \\
3(25 \%) \\
3.6(2.9)\end{array}$ & $p=0.70 / 0.67$ & $\begin{array}{l}n=31 \\
2(6 \%) \\
7(23 \%) \\
16(52 \%) \\
6(19 \%) \\
3.3(3.0)\end{array}$ & N/A & N/A \\
\hline $\begin{array}{l}\text { Physical abuse } \\
\text { Yes }\end{array}$ & $\begin{array}{l}n=71 \\
61(86 \%)\end{array}$ & $\begin{array}{l}n=33 \\
27(82 \%)\end{array}$ & $p=0.51 / 0.29$ & $\begin{array}{l}n=104 \\
88(85 \%)\end{array}$ & $\begin{array}{l}n=27 \\
16(59 \%)\end{array}$ & $p=0.0071 / 0.045$ \\
\hline $\begin{array}{l}\text { Perpetrator of physical abuse } \\
\text { Street children } \\
\text { Relative } \\
\text { Police } \\
\text { Self }\end{array}$ & $\begin{array}{l}n=58 \\
21(36 \%) \\
18(31 \%) \\
14(24 \%) \\
5(9 \%)\end{array}$ & $\begin{array}{l}n=26 \\
9(35 \%) \\
8(31 \%) \\
4(15 \%) \\
5(19 \%)\end{array}$ & $p=0.59 / 0.43$ & $\begin{array}{l}n=84 \\
30(36 \%) \\
26(31 \%) \\
18(21 \%) \\
10(12 \%)\end{array}$ & $\begin{array}{l}n=16 \\
5(31 \%) \\
6(38 \%) \\
3(19 \%) \\
2(12 \%)\end{array}$ & $p=0.96 / 0.21$ \\
\hline $\begin{array}{l}\text { Sexual abuse } \\
\text { Yes }\end{array}$ & $\begin{array}{l}n=45 \\
4(9 \%)\end{array}$ & $\begin{array}{l}n=29 \\
11(38 \%)\end{array}$ & $p=0.0019 / 0.15$ & $\begin{array}{l}n=74 \\
15(20 \%)\end{array}$ & $\begin{array}{l}n=27 \\
3(11 \%)\end{array}$ & $p=0.26 / 0.85$ \\
\hline $\begin{array}{l}\text { Problems with the police } \\
\text { Yes }\end{array}$ & $\begin{array}{l}n=66 \\
61(92 \%)\end{array}$ & $\begin{array}{l}n=26 \\
26(100 \%)\end{array}$ & $p=0.15 / N / A$ & $\begin{array}{l}n=92 \\
87(95 \%)\end{array}$ & $\begin{array}{l}n=26 \\
10(38 \%)\end{array}$ & $p<0.001 /<0.001$ \\
\hline $\begin{array}{l}\text { Beat with sticks by the police } \\
\text { Yes }\end{array}$ & $\begin{array}{l}n=62 \\
54(87 \%)\end{array}$ & $\begin{array}{l}n=24 \\
23(96 \%)\end{array}$ & $p=0.24 / 0.74$ & $\begin{array}{l}n=86 \\
77(90 \%)\end{array}$ & $\begin{array}{l}n=1 \\
1(100 \%)\end{array}$ & N/A \\
\hline
\end{tabular}

orphanage was assessed in table 3. For all characteristics except gender (for which the unadjusted odds ratio was 4.5), the age adjusted and unadjusted odds ratios were similar, suggesting no confounding by age. An older age ( $\mathrm{OR}=1.32$ / year, $95 \%$ CI 1.2 to 1.5$)$ and female gender (OR $=2.8,95 \%$ CI 0.7 to 10.7) were associated with being on the street. The strongest correlate was problems with police, with odds ratio 16.5 (95\% CI 4.6 to 59.1). The drug use variables and income through stealing and through begging were also strong correlates with odds ratios between 4 and 9, as was report of a health problem $(\mathrm{OR}=4.6,95 \% \mathrm{CI} 1.8$ to 11.2$)$ and physical abuse (OR $=3.0,95 \% \mathrm{CI} 1.1$ to 8.4). In addition, a longer time since most recent formal education was associated with being on the street (OR $=1.9 /$ year, 95\% CI 1.3 to 2.7 ), especially when evaluated as currently enrolled versus not enrolled in school (OR $=22.6,95 \%$ CI 6.8 to 75.2$)$. Through backwards selection and experimentation with a large number of possible multivariate models, we identified three models that fit well, each containing four independent variables (and these models control for age). The multivariable models show that drug use of each kind (paint thinner, glue, alcohol), problems with police, physical abuse, and absence from school are strongly independently associated with being on the street.

\section{DISCUSSION}

To our knowledge, a comparative analysis of abandoned street children and former abandoned street children in a geographical region has not previously been reported. It is postulated that the former abandoned street children represent a small, yet important, subset of the abandoned street child population. This study was able to determine a markedly different descriptive profile between the two populations. The life of an abandoned street child is marked by paint thinner use, physical violence, mental abuse, poor health, and employment in the informal sector. The results indicate that drug use, physical abuse, problems with the police, and absence from school were significantly more frequent for abandoned street children than for former abandoned street children. Importantly, police brutality or police harassment was the factor most strongly associated with the child being on the streets. This study will assist the street child worker to selectively focus on children who may be more likely to leave the streets and remain in a stable home environment.

Based on the analysis and our experience on the streets over the last seven years it is suspected that the child's most dynamic phase of change may be during the preadolescent years and less than two to four years on the streets. There may be a small window of time in which an abandoned street child has the greatest rehabilitative potential. In fact, the descriptive indicators of drug use, physical abuse, problems with the police, and absence from school may simply be secondary to time spent on the streets, the adolescent years, or some other unknown underlying factor. The research findings establish associations and not causation. 


\begin{tabular}{|c|c|c|c|c|}
\hline & Variable & Odds ratio & $95 \% \mathrm{Cl}$ & $\mathrm{p}$ value \\
\hline \multicolumn{5}{|c|}{ Individual variable models controlling for age } \\
\hline & Female gender & 2.8 & 0.7 to 10.7 & $p=0.014$ \\
\hline & Older age & $1.3 /$ year & 1.2 to 1.5 & $p<0.001$ \\
\hline & More years on street & 1.4/year & 1.1 to 1.7 & $p=0.001$ \\
\hline & Longer time since last educated & 1.9/year & 1.3 to 2.7 & $p=0.002$ \\
\hline & Not currently in school & 22.6 & 6.8 to 75.2 & $p<0.001$ \\
\hline & \multicolumn{3}{|l|}{ Method of income } & $p<0.001$ \\
\hline & Service (sings, shines, or sells) & 1.0 & & \\
\hline & Steals & 8.9 & 1.1 to 73.7 & $p=0.042$ \\
\hline & Begs & 4.6 & 1.2 to 18.6 & $p=0.031$ \\
\hline & Other & 0.4 & 0.1 to 1.6 & $p=0.20$ \\
\hline & Reported a health problem & 4.6 & 1.8 to 11.2 & $\mathrm{p}<0.001$ \\
\hline & Paint thinner use & 8.0 & 2.9 to 22.5 & $p<0.001$ \\
\hline & Longer duration paint thinner use & $3.6 /$ year & 1.3 to 10.0 & $p=0.013$ \\
\hline & Use of glue adhesive & 4.3 & 1.2 to 15.6 & $p=0.029$ \\
\hline & Alcohol use & 6.8 & 1.8 to 25.5 & $p=0.004$ \\
\hline & Physical abuse & 3.0 & 1.1 to 8.4 & $p=0.033$ \\
\hline & Problems with police & 16.5 & 4.6 to 59.1 & $p<0.001$ \\
\hline \multicolumn{5}{|c|}{ Multivariate models controlling for age } \\
\hline \multirow[t]{4}{*}{ Model I } & Not currently in school & 23.6 & 4.6 to 121.0 & $p<0.001$ \\
\hline & Paint thinner use & 6.8 & 1.1 to 41.3 & $p=0.038$ \\
\hline & Alcohol use & 6.9 & 1.2 to 41.0 & $p=0.033$ \\
\hline & Problems with police & 7.3 & 1.2 to 45.4 & $p=0.032$ \\
\hline \multirow[t]{4}{*}{ Model II } & Paint thinner use & 6.1 & 1.3 to 28.2 & $p=0.020$ \\
\hline & Alcohol use & 7.3 & 1.3 to 41.5 & $p=0.024$ \\
\hline & Physical abuse & 4.0 & 0.9 to 17.7 & $p=0.073$ \\
\hline & Problems with police & 11.0 & 2.5 to 48.9 & $p=0.002$ \\
\hline \multirow[t]{4}{*}{ Model III } & Older age & $1.2 /$ year & 1.0 to 1.5 & $p=0.041$ \\
\hline & Use of glue adhesive & 3.7 & 0.9 to 15.0 & $p=0.063$ \\
\hline & Alcohol use & 5.6 & 1.4 to 22.0 & $p=0.014$ \\
\hline & Physical abuse & 3.0 & 1.0 to 9.2 & $p=0.051$ \\
\hline
\end{tabular}

Nevertheless, these known variables will allow the street children workers to identify a subset of abandoned street children that may be more likely to permanently leave the street.

As with any research that focuses on human subjects, but more importantly street children, there are limitations. One of the concerns was the small sample size and a self-selection bias of the abandoned street child population and former abandoned street children. Large samples are difficult to obtain for abandoned street children who are often hiding in dark alleyways, sewers, trees, or in tunnels. Moreover, one questions whether the findings can be generalised to the abandoned street child population worldwide. Another limitation was the possibility of inaccurate responses from children. Oftentimes, the children may have given the "expected" answers, using paint thinner shortly prior to the interview, or distracted by others. In addition, some data were missing because children did not answer all questions, which sometimes stemmed from a lack of interest or a distracting environment.

Attempts were made to assure accuracy by interviewing the children with the same questionnaire on multiple occasions. There is a potential for recall bias in the former street children recounting characteristics of their former lives on the streets. In addition, our descriptive characterisation of the children may have missed important variables. There may be as yet unidentified "resiliency" factors that allow a child to leave the streets and stay off of the streets permanently. We appreciate the numerous limitations outlined above; however, conducting a systematic analysis in populations such as this is extremely difficult. Factors limiting the scope of potential bias include the facts that almost all children approached were willing to participate in the study, orphanage residents voluntarily chose to enter the orphanage, and the studied children were accurately classified as abandoned (or formerly abandoned) street children. This study adds to the knowledge of life on the streets for a child.

The phenomenon of abandoned street children poses a complex social challenge. This research defined many characteristics of the lives of La Paz street children, as a whole, and in street boys and girls separately. In addition, the study identified several variables that discriminate between abandoned street children and former abandoned street children who chose to enter a home. Younger age, time spent on the street, violence, drug use, and the lack of education seem to be major risk factors in the lives of street children. As a result of limited resources, one must focus efforts on children with the highest rehabilitative potential or greatest resiliency. By recognising these characteristics, we can more intelligently refine our efforts in prevention, intervention, and possibly rehabilitation. Application of the knowledge has led us to build a new model for addressing the tragedy. While attempting to address the needs of all of the abandoned street children, our staff workers focus on children who are younger, spent less time on the streets, experienced less violence, used less drugs, and had fewer years away from school. We encourage these children to go to local street children homes or into our home in La Paz for abandoned street children, Hogar Bernabe.

We, as a society, must read the proverbial writing on the walls especially when the street child writes it.

"Drugs and alcohol can kill me, but o shit, not fast enough." (Graffiti found on the walls of Paseo Marina Nunez, La Paz, Bolivia)

\section{ACKNOWLEDGEMENTS}

The authors thank Dr Howard Bauchner and Dr Paul Wise for reviewing and editing this manuscript. 


\section{Authors' affiliations}

C-C Huang, Department of Pediatrics, Boston University School of Medicine and Boston Medical Center, Division of Social Medicine and Health Inequalities, Harvard Medical School, and Brigham and

Women's Hospital, Boston, MA, USA

P Barreda, V Mendoza, L Guzman, Bolivian Street Children Project and Hogar Bernabe, La Paz, Bolivia

P Gilbert, Department of Biostatistics, University of Washington and Fred Hutchinson Cancer Research Center, Seattle, WA, USA

\section{REFERENCES}

1 United Nations, Department of International Economic and Social Affairs. The situation of youth in the 1980s and prospects and challenges for the year 2000. New York, NY: United Nations, 1986.

2 UNICEF. La ninez y la mujer en Bolivia: Analisis de situacion. La Paz, Bolivia: UNICEF, 1994:103.

3 Domic J. Menores en Bolivia ... Sujetos sociales hoy o manana? La Paz, Bolivia: San Gabriel, 1991:178.

4 United Nations Children's Fund. The state of the world's children. Geneva, Switzerland: UNICEF, 1996.
5 Ennew J, Milne B. The next generation: lives of third world children. London: Zed, 1989.

6 Lalor K. Street children: a comparative perspective. Child Abuse Negl 1999:23:759-70.

7 Fernandes $\mathbf{E}$. Extrajudicial execution of children: shortcomings of social citizenship and the fallacy of criminal justice in Brazil. Netherlands Quarterly on Human Rights 1994;12:117-35.

8 Inciardi J, Surratt H. Children in the streets of Brazil: drug use, crime, violence and HIV risks. Substance Use and Misuse 1998;33:1461-80.

9 UNICEF. Latin American Seminar on Community Alternatives for Street Children. Brasilia, Brazil, 12-15 November 1984.

10 UNICEF. The state of the world children. London, 1992.

11 Martins S, Ebrahim G. The female street children of Rio de Janeiro: a qualitative study of their backgrounds. J Trop Pediatr 1995;41:43-6.

12 Wright J, Kaminsky D, Wittig M. Health and social conditions of street children in Honduras. Am J Dis Child 1993;147:279-83.

13 Aptekar L. Characteristics of the street children of Columbia. Child Abuse Negl 1989;13:427-37.

14 Beyene Y, Berhane Y. Characteristics of street children in Nazareth, Ethiopia. East Afr Med J 1997;74:85-8.

15 Aneci C, Borba E, Ebrahim G. The Street Children of Recife: a study of their background. J Trop Pediatr 1992;38:34-40.

16 Hosmer D, Lemeshow S. Applied logistic regression. New York: John Wiley and Sons, 1989.

\section{ARCHIVIST}

\section{Post-traumatic stress in child soldiers}

shall make no comment about this paper; to do so might give vent to my own emotions but it would serve no other useful purpose and you will no doubt experience similar reactions.

In 2001 it was estimated that in more than 50 countries around the world there were around 300000 child soldiers. A group of Belgian workers has tried to assess the effects of soldiering and abduction on 301 children in northern Uganda (Ilse Derluyn and colleagues. Lancet 2004;363:861-3; see also editorial, ibid: 831). The organisation Sponsoring Children Uganda runs a rehabilitation centre for former child soldiers in the town of Gulu and 473 children and young adults are involved in the programme. They are former members of the Lord's Resistance Army (LRA) which recruits mainly by abduction of children; about $90 \%$ of its recruits are children and it has abducted some 20000. The researchers interviewed 301 former soldiers all of whom had been abducted. At the time of interview their ages ranged from 12 to 28 years. They had been between one and 22 years old when abducted and had spent between 3 days and 3000 days ( 8.2 years) in the army. They had returned between 59 and 3420 days ( 9.4 years) before the study. Most had experienced many traumatic events. Two hundred and thirty-three of the 301 had witnessed a killing; 118 had themselves killed somebody; 18 saw the killing of their own parents or siblings; and seven killed their own father, brother, or other relative. Twenty-one of the 53 girls were sexually abused and 11 had had a child.

Seventy-one former soldiers completed the impact event scale-revised (IES-R), a selfreport scale for the diagnosis of post-traumatic stress disorder (PTSD). Sixty-nine of the 71 had a score suggestive of PTSD. With the IES-R a score of 24 is regarded as clinically significant and the maximum possible score is 88; among the 71 former solders scores ranged from 18-81 and the mean score was 53.5. The death of their mother affected girls much more than boys. IES-R scores were not affected by age, duration of captivity, or length of time since captivity. These young people are often ostracised by their own communities because of their crimes.

The Lancet accuses the United Nations of producing platitudes rather than effective plans to combat the evil and calls for resources to be put into post-war rebuilding of broken societies. Leaders of the Lord's Resistance Army are to be brought before the International Criminal Court. 